\title{
Larval release and supply predict temporal variation in settlement of a colonial ascidian
}

\author{
C. J. Hurlbut* \\ Department of Zoology, University of Hawaii, Honolulu, Hawaii 96822, USA
}

\begin{abstract}
Temporal variation in the number of larvae released, number of planktonic larvae, and settlement density was examined for the colonial ascidian Didemnum candidum Savigny, 1816 in Pearl Harbor, Hawaii, USA. The influence of larval availability on settlement intensity was estimated by counting larvae released from adults placed in traps and by sampling larvae in the plankton with a plankton pump. Diel timing of larval settlement was measured by counting newly-settled juveniles on acrylic plates immersed for consecutive 1 or $2 \mathrm{~h}$ periods throughout the day. Larval release, planktonic larvae and settlement occurred only during the daytime, with a strong early morning and weaker afternoon peak in abundance. Diel variation in larval release and abundance of planktonic larvae accounted for a large part of the variation in settlement. The close temporal link between larval release and settlement indicates that planktonic larval availability, as controlled by larval release, is an important determinant of settlement intensity in $D$. candidum.
\end{abstract}

\section{INTRODUCTION}

Patterns of larval settlement can be primary determinants of community structure for benthic marine invertebrates (Underwood \& Denley 1984, Connell 1985, Gaines \& Roughgarden 1985), and have frequently been attributed to spatial and temporal patterns of larval distribution (e.g. Grosberg 1982, Yoshioka 1982, Gaines et al. 1985, Olson 1985). Larval supply, or the number of competent larvae that contact a substratum (Roughgarden et al. 1988), is a function of the number of larvae initially produced and the number of those larvae that survive the planktonic phase and reach a suitable settlement site. Thus, larval supply can be affected both by adult reproductive activity and by survival and dispersal of larvae in the plankton.

The degree to which initial larval production dictates larval supply varies with the duration of the planktonic period. In species with long-lived larvae, larval production and larval supply are more likely to be decoupled by larval loss than in species with short-lived larvae, where larval loss is limited by the brevity of the planktonic period. For short-lived larvae, larval release rates should therefore predict larval supply, and larval pro-

- Present address: Harbor Branch Oceanographic Institution, 5600 Old Dixie Highway, Fort Pierce, Florida 34946, USA duction should be more important than planktonic events in determining the number of larvae that reach settlement sites.

Lecithotrophic larvae of some epifaunal invertebrates have a planktonic period of minutes to hours in the laboratory (e.g. colonial ascidians, Svane \& Young 1989; bryozoans, Ryland 1974; some sponge species, Berquist et al. 1970). For example, larvae of colonial ascidians settle within minutes of release in the field (Duyl et al. 1981, Olson 1983, Davis \& Butler 1989, Stoner 1990). The number of colonial ascidian larvae released can vary on a daily (Davis 1989) or an hourly (Olson 1983) basis. This close temporal link between release and settlement means that temporal variation in larval production should be reflected in a corresponding variation in larval supply.

The goal of this study was to determine, for a sessile invertebrate with short-lived larvae, if larval release predicts larval supply, and if larval supply in turn predicts settlement. Alternatively, release and settlement could be decoupled by high levels of predation or dispersal. The colonial ascidian Didemnum candidum Savigny, 1816 is an abundant member of the fouling community in Pearl Harbor, Hawaii, USA, and has larvae that settle within seconds to up to $5 \mathrm{~h}$ after release in the laboratory (unpubl. data). For this ascidian, I measured diel patterns of larval release, planktonic availability of larvae and larval settlement. 


\section{METHODS}

Planktonic larvae and newly-settled juveniles were counted concurrently in 1987, while larval release and settlement were assessed together in 1988. Settlement data were obtained during both years and were used to evaluate variation in the timing of these events between years. The study site and methods are described in Hurlbut $(1988,1991)$, where the 1987 data were used to compare the timing of settlement of Didemnum candidum and 2 related ascidians (Hurlbut 1988 ) and to examine variation in settlement of $D$. candidum with depth (Hurlbut 1991).

The number of larvae released per hour was measured during the daytime from adult colonies growing on acrylic plates. Five larval traps were constructed of translucent plastic sandwich boxes. The traps were filled with seawater that had been filtered through a $125 \mu \mathrm{m}$ mesh sieve and a Didemnum candidumencrusted plate was bolted to the inside of each lid. The traps were suspended vertically from the side of the dock $0.25 \mathrm{~m}$ below the water surface. Every hour between $05: 00 \mathrm{~h}$ and 18:00 $\mathrm{h}$ on 21,26 and 28 July 1988 , the water in each trap was filtered through a $125 \mu \mathrm{m}$ mesh sieve and the captured larvae were preserved in $10 \%$ formalin. The traps were then filled with freshly filtered seawater and redeployed. Release was not measured between 18:00 h and 05:00 h. Larvae of $D$. candidum glow in cross-polarized light and are easily identifiable. No larvae settled inside the traps, which were hydrophobic. While conditions inside the traps may have differed from ambient water conditions, any 'trap effects' are assumed to have been fairly constant throughout the day. This assumption is supported by the close correspondence between the results obtained here and data collected in the laboratory using a flow-through seawater system (Hurlbut 1988).

On 21, 26 and 28 July 1988, light readings were taken once an hour between 05:00 h and 18:00 h at $0.25 \mathrm{~m}$ depth with a quantum scalar irradiance meter (Biospherical Instruments, Inc. QSL-100).

Plankton samples were taken using the methods described in Hurlbut (1991). Replicate 82.51 samples were taken with an impellar pump at $0.25 \mathrm{~m}$ every $2 \mathrm{~h}$ over a $24 \mathrm{~h}$ period on 25 July and 1, 8 and 15 August 1987. Larvae of Didemnum candidum in the samples were preserved for identification and enumeration. Larvae occasionally lost their tails during passage through the pump but were otherwise intact and readily identifiable.

Larval settlement was measured on the undersides of sanded, black acrylic plates $(82 \times 103 \mathrm{~mm})$ suspended horizontally $0.25 \mathrm{~m}$ below the water surface for consecutive 1 or $2 \mathrm{~h}$ periods. First, bi-hourly variation in settlement over $24 \mathrm{~h}$ was measured on the same days that plankton samples were taken (25 July and 1, 8 and 15 August 1987). Five replicate plates were deployed every $2 \mathrm{~h}$ at a location $2.5 \mathrm{~m}$ away from the intake of the plankton pump, then retrieved after $2 \mathrm{~h}$ of immersion. Second, hourly settlement was measured concurrently with larval release between 05:00 h and 18:00 h on 21 and 26 July 1988, with 5 replicate plates deployed every hour adjacent to the larval traps. At the end of each sampling day, settled juveniles of Didemnum candidum on the plates were identified and counted.

Temporal variation in the number of larvae captured by each method was examined with Pearson productmoment correlations and regression analyses. Data were $\log$-transformed $(\log X+1)$ to avoid hetero-
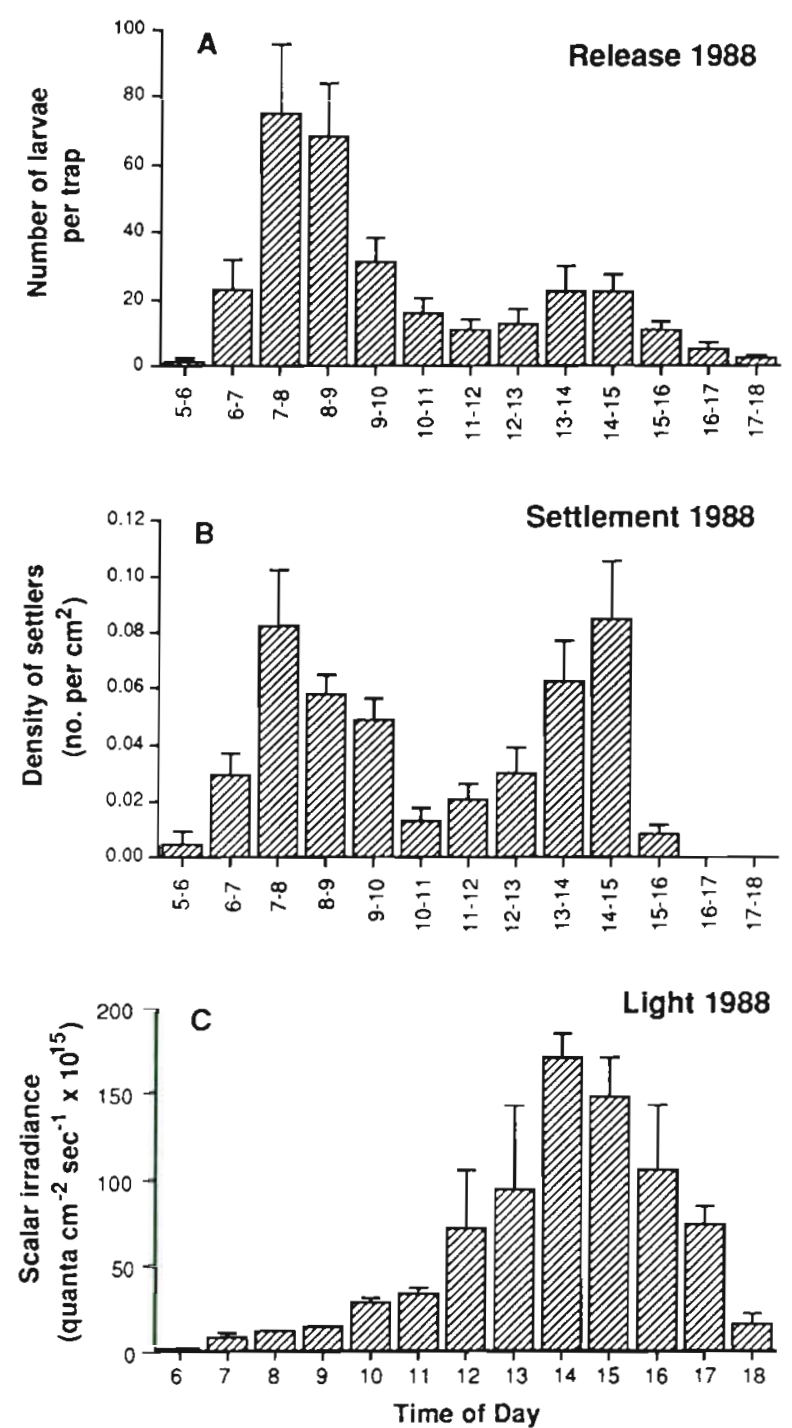

Fig. 1 Didemnum candidum. Hourly variation in abundance of larval release and settlement and in irradiance (mean +1 SE). (A) Number of larvae released in each larval trap $h^{-1}$ (B) Density of settlers $\mathrm{h}^{-1}$. (C) Scalar irradiance measured hourly 
scedasticity (Sokal \& Rohlf 1981). Comparisons of data among all 3 sampling methods were made with the 1988 data pooled into $2 \mathrm{~h}$ intervals.

\section{RESULTS}

Larvae of Didemnum candidum were present only during the daytime. Larval release, abundance of planktonic larvae, and settlement showed a strong early morning peak and a weaker afternoon peak in intensity (Fig. 1). For all 3 sampling methods, larvae were first captured near dawn, between 05:00 h and 06:00 h. No larvae were captured in the planktonic
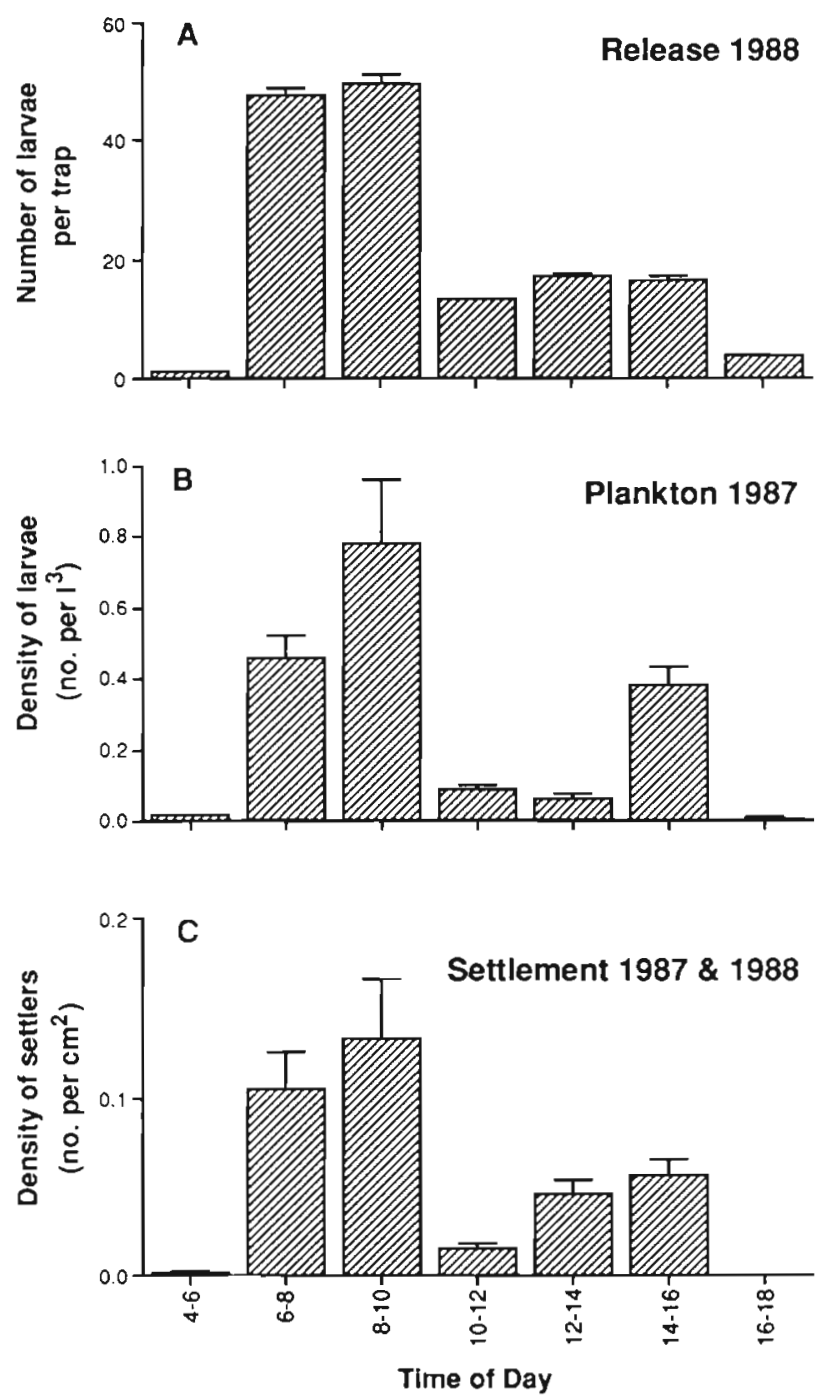

Fig. 2. Didemnum candidum. Abundance of larvae released, in the plankton and settling in $2 \mathrm{~h}$ periods (mean $+1 \mathrm{SE}$ ). (A) Number of larvae released per larval trap. (B) Density of larvae in the plankton. (C) Density of settled juveniles. No larvae were captured in the plankton or settled between 18:00 h and 04:00 h phase or settled between 18:00 h and 05:00 h. Release was not measured at night. Irradiance reached a maximum of $175 \times 10^{15}$ quanta $\mathrm{cm}^{-2} \mathrm{~s}^{-1}$ at 14:00 h. Hourly settlement did not closely follow the pattern of increase in light over the daylight hours, although the second peak in settlement (14:00 to 15:00 h) was near the time of peak light level (Fig. 1C).

The diel timing of release, planktonic abundance and settlement were significantly correlated with each other (Pearson product-moment correlation: releaseplankton $\mathrm{r}=0.873, \mathrm{p}=0.010$; release-settlement $\mathrm{r}=$ $0.864, p=0.012 ;$ plankton-settlement $r=0.941, p=$ 0.002 ). These 3 measurements did not show identical patterns. Larvae were released and captured in the planktonic phase between 16:00 $\mathrm{h}$ and 18:00 $\mathrm{h}$, but very few settlers were found at this time, suggesting that larvae released late in the day had poor settlement success. When release and settlement were compared in $1 \mathrm{~h}$ intervals, the same bimodal distribution was apparent (Fig. 2A, B); pooling the data into $2 \mathrm{~h}$ samples did not obscure the general pattern (Fig. $1 \mathrm{~A}, \mathrm{C}$ ).

The diel pattern of settlement did not differ significantly between 1987 and 1988 (Pearson productmoment correlation, $\mathrm{r}=0.951, \mathrm{p}=0.001)$. The average number of settlers per day was similar in 1987 and 1988 $\left(\right.$ mean \pm 1 SE: $212 \pm 90,189 \pm 50$ settlers $d^{-1}$, respectively).

Variation in the time of larval release accounted for $74 \%$ of the variation in settlement intensity in 1988 (regression analysis, $\mathrm{T}=3.75, \mathrm{p}=0.013$ ). Even though larval release and planktonic larval abundance were measured in different years, larval release accounted for $69 \%$ of the variation in planktonic larvae $(T=3.35$, $p=0.020)$. Variation in the temporal abundance of larvae in the plankton accounted for $92 \%$ of the variation in settlement in $1987(\mathrm{~T}=7.51, \mathrm{p}<0.001)$.

\section{DISCUSSION}

Patterns of larval availability can control the distribution and intensity of settlement of benthic invertebrates (Keough 1988, Roughgarden et al. 1988). My field results indicate that larval release and settlement of the colonial ascidian Didemnum candidum were closely linked in time, and that variation in release and the abundance of planktonic larvae accounted for a large part of the variance in settlement. Thus, the timing of larval release was the most important proximate factor determining larval availability, which, in turn, largely determined the timing of settlement. Larval release and settlement are unlikely to show a similar close association in species with long-lived larvae. Larval mortality and dispersal distance probably increase with larval lifespan (Strathmann 1985, Young \& Chia 1987), and 
extensive planktonic mortality or dispersal could weaken the correlation between larval release and settlement at a given site.

The close temporal link between larval release and settlement of Didemnum candidum suggests that the planktonic period is brief in the field. In the laboratory, larvae of colonial ascidians generally settle within minutes or hours of release, although there is variability both within and between species (Millar 1971, Berrill 1975). In the field, larvae of several species have been observed to settle within seconds to minutes of release (Olson 1983, Davis \& Butler 1989, Stoner 1990). For $D$. candidum, both release and settlement occurred during the first hour of sampling in the early morning. Since planktonic larvae were never found at night, this early settlement probably resulted from rapid settlement of newly-released larvae, rather than from settlement of larvae that remained planktonic overnight and settled at first light the next morning.

Short-lived larvae are assumed to experience relatively low mortality in the planktonic phase and to have limited dispersal (Strathmann 1985). In fact, in situ observations of short-lived ascidian larvae have found disparate levels of larval mortality due to fish predation (47\%, Olson \& McPherson 1987; 4\%, Stoner 1990). Larvae of Didemnum candidum are readily eaten by juvenile tilapia Oreochromis mossambicus in the laboratory (unpubl. data). This fish is abundant in Pearl Harbor and may be an important predator of ascidian larvae in the field. While larval loss was not directly assessed in the present study, the temporal relationship between release and settlement could have been maintained despite high levels of predation, provided that the rate of loss was constant throughout the day.

Dispersal distance in the field is limited for larvae of several species of colonial ascidians, on the order of a few meters at most (Olson 1983, Grosberg 1987, Davis \& Butler 1989). Planktonic larvae and settlement of Didemnum candidum are most abundant at the same depth at which the adults occur (Hurlbut 1991), implying that most larvae of $D$. candidum released at this site probably settle near their parents. The absence of strong turbulence or currents at the study site probably contributes to limited dispersal distance; dispersal may be greater in an environment with more water motion.

In species with short-lived larvae such as Didemnum candidum, larval release time predicts settlement time (Olson 1983, Davis 1988, present study). Thus, by controlling release time, adults control the timing of settlement. Larval release is stimulated by light in a number of groups (e.g. colonial ascidians, Svane \& Young 1989; bryozoans, Ryland 1974; sponges, Amano 1988), suggesting that release occurs shortly after dawn in the field. For larvae with a lifespan of a few hours, release in the early morning ensures settlement during day- light hours. This may have a significant impact on the spatial distribution of settlement, because environmental conditions used by larvae as settling cues may vary with time of day.

For many benthic invertebrates, the ultimate selective pressure affecting the time of larval release may be the potential influence of light level on larval behavior. Light can be an important cue used by larvae to locate settlement sites where chances of juvenile survival are high (Thorson 1964, Meadows \& Campbell 1972). In the laboratory, larvae of colonial ascidians are commonly photonegative prior to settlement (Millar 1971), which may lead them to seek out dark crevices and under-surfaces for settlement (Millar 1971, Young \& Chia 1984, Cloney 1987). In the field, settlement of ascidian larvae is greater in shaded locations (Olson 1983. Hurlbut 1990) and survival is higher in such sites (Olson 1983, Young \& Chia 1984, Hurlbut 1990).

Larvae of some colonial ascidians with symbiotic algae settle predominantly at midday, when light intensity is maximal and larvae are most likely to detect shaded settlement sites (Olson 1983). The present study reports midday settlement for a colonial ascidian that does not contain symbiotic algae. Larvae of Didemnum candidum settle predominantly in shaded locations in both the laboratory and field, and survival is greater when juveniles are protected from direct sunlight (Hurlbut 1990). Thus, settlement during daylight hours has adaptive value for $D$. candidum.

Acknowledgements. I am indebted to those who helped me with the overnight sampling. The comments of Drs M.G. Hadfield, W. B. Jaeckle, J. M. Lawrence, S. R. Palumbi and C.M. Young improved the manuscript. This research was funded by the American Museum of Natural History and the Sigma Xi Society. Harbor Branch Oceanographic Institution Contribution No. 889.

\section{LITERATURE CITED}

Amano, S. (1988). Morning release of larvae controlled by the light in an intertidal sponge, Callyspongia ramosa Biol. Bull. 175: 181-184

Bergquist, P. R., Sinclair, M. E., Hogg, J. J. (1970). Adaptation to intertidal existence: reproductive cycles and larval behavior un Demospongiae. Symp. zool. Soc. Lond. 25: $247-271$

Berrill, N. J. (1975). Chordata: Tunicata. In: Giese, A. C., Pearse, J. S. (eds.) Reproduction of marine invertebrates, Vol. II. Blackwell Scientific Publications, Oxford, p. $241-282$

Cloney, R. A. (1987). Phylum Urochordata, Class Ascidian. In: Strathmann, M. F. (ed.) Reproduction and development of marine invertebrates of the northern Pacific coast. University of Washington Press, Seattle, p. 507-540

Connell, J. H. (1985). The consequences of variation in initial settlement versus post-settlernent mortality in rocky intertidal commurities. J. exp. mar. Biol. Ecol. 93: 11-45

Davis, A. R. (1988). Effects of variation in initial settlement on 
distribution and abundance of Podoclavella moluccensis Sluiter. J. exp. mar. Biol. Ecol. 117· 157-167

Davis, A. R. (1989). Temperature correlates with the daily release of larvae and their settlement in a temperate Australian ascidian. In: Ryland, J. S., Tyler, P. A. (eds.) Reproduction, genetics and distribution of marine organisms. Proc. 23rd. Eur. mar biol. Symp. Olsen \& Olsen, Fredensborg, p. 61-65

Davis, A. R., Butler, A. J. (1989). Direct observations of larval dispersal in the colonial ascidian Podoclavella moluccensis Sluiter: evidence for closed populations. J. exp. mar Biol. Ecol. 127: 189-203

Duyl, F. C. van, Bak, R. P. M., Sybesma, J. (1981). The ecology of the tropical compound ascidian Trididemnum solidum. I. Reproductive strategy and larval behavior Mar Ecol. Prog. Ser. 6: 35-42

Gaines, S., Roughgarden, J. (1985). Larval settlement rate: a leading determinant of structure in an ecological community of the marine intertidal zone. Proc. Nat. Acad. Sci. U.S.A. 82: $3707-3711$

Gaines, S., Brown, S., Roughgarden, J. (1985). Spatial variation in larval concentrations as a cause of spatial variation in settlement for the barnacle, Balanus glandula. Decologia 67: 267-272

Grosberg, R. K. (1982). Intertidal zonation of barnacles: the influence of planktonic zonation of larvae on vertical distribution of adults. Ecology 63: 894-899

Grosberg, R. K. (1987). Limited dispersal and proximitydependent mating success in the colonial ascidian Botryllus schlosseri. Evolution $41 \quad 372-384$

Hurlbut, C. J. (1988). Diel timing of larval release and settlement of colonial tunicates in Pearl Harbor, Oahu, Hawaii. In: Choat, E. H. et al. (eds.) Proc. 6th Inter. Coral Reef Symp. Sixth International Coral Reef Symposium Executive Committee, Townsville 2: 733-737

Hurlbut, C. J. (1990). Variations in larval density and settlement in space and time: important determinants of recruitment in sessile marine invertebrates? Ph.D. dissertation, University of Hawaii, Honolulu

Hurlbut, C. J. (1991). The effects of larval abundance, settlement and juvenile mortality on the depth distribution of a colonial ascidian. J. exp. mar. Biol. Ecol. 150: 183-202

Keough, M. J. (1988). Benthic populations: Is recruitment limiting or just popular? In: Choat, E. H, et al. (eds.) Proc. 6th Inter. Coral Reef Symp. Sixth International Coral Reef Symposium Executive Committee, Townsville 1: 141-148

Meadows, P. S., Campbell, J. I. (1972). Habitat selection by aquatic invertebrates. Adv mar Biol. 10: 271-382

This article was presented by J. M. Lawrence, Tampa, Florida, USA
Millar, R. H. (1971). The biology of ascidians. Adv. mar. Biol. 9: $1-100$

Olson, R. R. (1983). Ascidian-Prochloron symbiosis: the role of larval photoadaptation in midday larval release and settlement. Biol. Bull. 165: 221-240

Olson, R. R. (1985). The consequences of short-distance larval dispersal in a sessile marine invertebrate. Ecology 66:30-39

Olson, R. R, McPherson, R. (1987). Potential vs. realized larval dispersal: fish predation on larvae of the ascidian Lissoclinum patella (Gottschaldt). J. exp. mar. Biol. Ecol. 110: $245-256$

Roughgarden, J., Gaines, S., Possingham, H. (1988). Recruitment dynamics in complex life cycles. Science 241. $1460-1466$

Ryland, J. S. (1974). Behavior, settlement, and metamorphosis of bryozoan larvae: a review. Thalassia jugosl. 10: 239-262

Sokal, R. R., Rohlf, F. J. (1981). Biometry. W. H. Freedman \& Co., New York

Stoner, D. S. (1990). Recruitment of a tropical colonial ascidian: relative importance of pre-settlement vs. post-settlement processes. Ecology 71: 1682-1690

Strathmann, R. R. (1985). Feeding and nonfeeding larval development and life-history evolution in marine invertebrates. Ann. Rev. Ecol. Syst. 16: 339-361

Svane, I., Young, C. M. (1989). The ecology and behavior of ascidian larvae. Oceanogr. mar Biol. A. Rev. 27: 45-90

Thorson, G. (1964). Light as an ecological factor in the dispersal and settlement of larvae of marine bottom invertebrates. Ophelia 1: 167-208

Underwood, A. J., Denley, E. J. (1984). Paradigms, explanations, and generalizations in models for the structure of intertidal communities on rocky shores. In: Strong, D., Simberloff, D., Abele, L. G., Thistle, A. B. (eds.) Ecological communities: conceptual issues and the evidence. Princeton University Press, Princeton, p. 151-180

Yoshioka, P. M. (1982). Role of planktonic and benthic factors in the population dynamics of the bryozoan Membranipora membranacea. Ecology 63: 457-468

Young, C. M., Chia, F.-S. (1984). Microhabitat-associated variability in survival and growth of subtidal solitary ascidians during the first 21 days after settlement. Mar. Biol. 81. $61-68$

Young, C. M., Chia, F.-S. (1987). Abundance and distribution of pelagic larvae as influenced by predation, behavior, and hydrographic factors. In: Giese, A. C., Pearse, J. S., Pearse, $V$ B. (eds.) Reproduction of marine invertebrates, Vol. IX. Blackwell Scientific Publications, Palo Alto, California, p. $385-464$

Manuscript first received: September 16, 1991

Revised version accepted: January 6, 1992 